\begin{tabular}{ll}
\hline \hline MINING AND METALLURGY INSTITUTE BOR & ISSN: 2334-8836 (Štampano izdanje) \\
UDK: 622 & ISSN: 2406-1395 (Online) \\
\hline \hline
\end{tabular}

Boško Vuković, Aleksej Milošević ${ }^{* *}$

\title{
POTENTIALITY OF THE RAW MATERIAL COAL BASE FROM THE GACKO DEPOSIT IN A FUNCTION OF PROVIDING THE ENERGY FUEL FOR STRATEGIC PLANNING OF THE TPP GACKO 2
}

\begin{abstract}
Coal resources, in addition to oil, gas and uranium as a non-renewable and hydropotential as a renewable energy source, represent the most significant part of energy potential and an energy source of strategic importance on the Republic of Srpska. The modern pace of technological and industrial development causes a permanent increase in coal exploitation and consumption. The use of this resource must be planned and extremely rational. Coal deposits in the Republc Srpska are differed in the structure and quantities of reserves, geological and technical-economic conditions of exploitation and quality. Geological reserves of the Gacko coal deposit amount to $330 \mathrm{Mt}$. According to the current geological documentation, the balance reserves are $\approx 182 \mathrm{Mt}$, with an energy potential of $545 \mathrm{TWh}$. According to the processed performance indicators, the balance and mineable reserves of coal enable a long-term supply of fuel for the current and future thermal power plant under the favorable economic conditions. In order to provide the required amount of energy for operation the existing and "new" thermal power plant in Gacko, it is necessary to carry out the geological explorations in order to reproduce the mineral and raw material base. The duty of every company engaged in exploitation the coal energy resources is a continuous performance of geological explorations in order to find the new ones or transfer the existing reserves into a higher category. The future development and level of coal production from the Gacko deposit will mostly depend on the electricity production in the Gacko Thermal Power Plant. It would certainly strive for fulfillment the basic conditions, i.e. the cost of coal heat utilization, as in many other countries, be at least approximately competitive with the cost of heat from the other primary energy sources (hydro sources, imported energy, etc.).In order that the Gacko non-renewable energy resource would survive and evolve in a particular environment, it must have a clearly defined purpose of existence. This purpose of existence is primarily reduced to a multiphase process of providing and using a non-renewable energy resource in accordance with the realistic natural, economic and ecological opportunities, in relation to which there are the expressed needs in a wider or narrower environment.

Keywords: coal, Gacko deposit, open pit, energy fuel, thermal power plant
\end{abstract}

\section{INTRODUCTION}

The Gacko field and carbonaceous Neogene sediments deposited in its former depression are located in the far southeast of the Republic of Srpska on the border with Montenegro. Three quarters of the fields are covered by the Quaternary sediments below which are the Neogene formations, covering an area of about $40 \mathrm{~km}^{2}$. The Neogene sediments are distributed over an area of about $16.5 \mathrm{~km}$ long, from

\footnotetext{
*Mine and TPP Gacko, Industrial zone bb,e-mail: bosko.vukovic@ ritegacko.com

${ }^{* *}$ Faculty of Mining Prijedor, University in Banja Luka, e-mail: aleksej.milosevic@ rf.unibl.org
} 
Nadanić in the northwest, to Gareva and Dobrelja in the southeast, with the maximum width of about $3 \mathrm{~km}$ [2].

The Gacko deposit contains lignite/brown-lignite coal type as an economic raw material type. It is used almost exclusively as a thermal energy fuel, for the needs of the Thermal Power Plant in Gacko and is one of the strategic raw materials of the Republic of Srpska. Coal from the Gacko deposit is a non-renewable energy mineral raw material of the primary economic importance for the Republic of Srpska.

The coal mines in the Republic of Srpska, during their production activities, encounter the specific problems, issues and challenges [10]. The same are related both to the quantity and quality of mineral raw materials, as well as to the organizational and production activity. They also share a need to improve and modernize the production and work organization technology. The latter is particularly pronounced in the case of the Gacko coal deposit, that is, the mine supplying the Gacko Thermal Power Plant with the raw material.

\section{COAL RESOURCES FROM GACKO - ENERGY FUEL FOR THE CURRENT AND FUTURE THERMAL POWER PLANTS}

Geological reserves of the Gacko coal deposit amount to $330 \mathrm{Mt}$ [8]. According to the current geological documentation, the balance reserves are $\approx 182 \mathrm{Mt}$, with an energy potential of $545 \mathrm{TWh}$. Due to the total quantity of ore reserves and quality, the Gacko coal deposit is the most important source of this raw material for the needs of thermal power plants in the Republic of Srpska.

The average coal bearing content in the Gacko coal deposit, by the individual coal seams, only for the main seam is $9.36 \mathrm{t} / \mathrm{m}^{2}$. For all three coal levels of the first coal seam, the average coal content is $13.73 \mathrm{t} / \mathrm{m}^{2}$. The second coal seam is characterized by the uniform development throughout the deposit with average coal content of $13.46 \mathrm{t} / \mathrm{m}^{2}$. The average coal bearing content in the contours of balance reserves of the roof seams of coal zone is $7.12 \mathrm{t} / \mathrm{m}^{2}$.

There are 36.1 Mt of coal in the Gacko coal deposit, category $\mathrm{C}_{2}$ mainly in the deepest parts of the Eastern Field. This practically means that there is a real potential for finding the new coal reserves in this area. If the new reserves would be found (for which there are favorable mineral genetic preconditions), the open pit life would be increased, so the coal mine in Gacko would be a long-term economic facility with a significant impact on development the other economies and social activities in the Municipality of Gacko. Within this, it is estimated that construction of the second and, in perspective the third phase of the Thermal Power Plant, has its full justification.

To evaluate the possibility of energy development on the basis of coal use from the deposit "Gacko", it is necessary to know the actual coal reserves, mining-geological conditions, hydrogeological conditions, geomechanical parameters of waste sediments (overburden), quality and usability of coal, possibility of development the cheaper surface exploitation, possibility of applications the modern mechanization at the open pit, i.e. mechanized high-performance complexes in surface exploitation. In principle, over a longer period of exploitation, it is realistic to expect a more pronounced impact of various risks, within which the geological, mining and economic risks are dominated. 


\section{TECHNOLOGICAL PROPERTIES OF THE RAW MATERIAL BASE OF COAL}

Technological properties of the raw material base of coal are determined by its mineral and chemical composition, structural-textural characteristics, granulometric characteristics, amount of useful and harmful or undesirable components, as well as the characteristics of their location in the deposit. For evaluation the coal quality from the Gacko deposit, its thermal value is of the greatest importance.

The use of raw lignite in a batch form in a wider and general consumption and industry is justified only within the economic transport radius because its thermal value is low. This means that the sale of pre-sorted raw lignite as fuel in smaller urban settlements (closer to the mine) would have the positive economic effects. However, most of the raw lignite produced from the Gacko deposit, as well as in the Republic of Srpska, is used in the thermal power plants for electricity generation [7].

The qualitative characteristics of coal as an energy fuel from the Gacko deposit have been defined by the classical immediate analyzes. The results of such research often deviate from those tested in practice. The coal quality studies were carried out in a manner that is not adapted to the requirements of selective exploitation. However, no low thermal value interlayers, such as clay coal or coal clays, were precisely defined, which also reduce the thermal value of coal. All of this had a direct effect on poor separation of the waste interlayers from coal and decrease of its thermal value. Coal intended as a thermal energy fuel and coal intended for the general consumption are delivered to the final consumers without additional technological processes for coal refining and classification.
The basic aspects of utilization the existing coal reserves, in order to obtain the quality fuel for the thermal power plant, require a professional and modern approach in order to obtain the adequate, maximally rational technological effects in the processes of coal production and combustion. Considering that coal is a heterogeneous raw material, that its composition and properties can differ from the same seam, there is a need to obtain as uniform and highquality characteristics as possible by the technological solutions and processes. For these reasons, all issues related to ensuring the guaranteed quality of coal as a fuel for the thermal power plant are directed to finding the technological solutions in order to improve and harmonize the quality of mined coal. Solving the problem of providing coal of uniform quality and composition can be realized through the technological process of refining (cleaning) the run-ofmine coal [5].

Previous solving the above problem in the mine has been in a direction of selection the optimum coal mining technology, which implied the application of selective exploitation. Coal in the deposit of the Gacko basin is of complex geological structure, layered with a large number of barren interlayers of low power and, therefore, very ungrateful for exploitation and preparation. Selective coal mining partially solves the problem, but due to the above characteristics of coal series, it encounters difficulties and does not produce the good enough results. It is obvious that the present exploitation results in a kind of dilution, i.e. a decrease in the quality of raw material, which is reflected in the lower thermal value of coal that is burned in comparison 
with the heat value, which, according to the research, was calculated for "clean" coal. As this problem has not been satisfactorily resolved previously, it should be considered as an important technical and exploitation factor and in future exploitation in the new Open Pit Gacko.

\section{THE OBJECTIVES OF THE DEVELOPMENT STRATEGY OF ENERGY SECTOR OF THE RS}

The general objective of the development strategy of thermal power sector is defined in the Energy Strategy of the Republic of Srpska until 2030. The strategic document defines the general objectives, which are the basis for strategic planning the development of the Gacko thermal power complex. The national strategic objectives are as follows [9]:

- Providing the required amount of energy, primarily coal, for the thermal power plants in order to ensure regular and secure electricity supply to the economy and citizens in the area of the Republic of Srpska. The provision of required energy amount should be done at economically sustainable prices, taking into account the problems of energy poverty;

- Increasing the efficiency of production the non-renewable energy resources;

- Creation the conditions for gradual opening the electricity market and investment in the thermal energy sector;

- Establishment an efficient system for promoting the thermal energy efficiency and use the non-renewable energy sources in accordance with the set goals and obligations that will result from the membership of Bosnia and Herzegovina in the EU;

- Providing a sustainable development of the thermal power sector under conditions of limited greenhouse gas emissions;

- Aligning the legislation with the legal heritage of the European Union.

An ambitious plan of development activities needs to be enacted and implemented to achieve these frameworkdefined objectives in the coal capacities of the Republic of Srpska. According to this plan, it is estimated that the planned volume of capital should be invested in a new and revitalization the existing equipment and other projects in the coal mines in the Republic of Srpska.

The total energy demand in the Republic of Srpska is met by the consumption of coal, liquid fuels, gaseous fuels, hydropower and firewood. Coal accounts for the largest share of total energy consumption about $40 \%$. Coal is predominantly used for the electricity production in the thermal power plants (over 90\%) while the rest is used for the other commercial purposes.

When considering the energy reserves and potential of the Republic of Srpska, coal represents the dominant energy feedstock with the total balance reserves of $684 \mathrm{Mt}, 390 \mathrm{Mt}$ of lignite and $294 \mathrm{Mt}$ of brown coal. This energy resource will continue to be based on the energy development of the Republic of Srpska, given that it is planned to increase the coal production up to $9.3 \times 10^{6}$ tons of coal by 2025 , with an estimate of investment in the coal production area in 2010-2030 of $655 \times 10^{6} \mathrm{KM}$.

\section{LONG-TERM COAL MINING STRATEGY FROM THE GACKO DEPOSIT}

Development strategy of the Gacko Thermal Power Complex, based on the basic document, has the main objective of countering the Gacko coal reserves, whose exploitation at economically favorable values can provide the energy fuel for both the 
existing and future Thermal Power Plant Gacko 2. On the basis of this, the main objectives have been defined for development the strategic document "Strategy of Mining and Technological Opening, Development, Optimization and Maintenance of the Coal Production Continuity with Preparation the Feasibility Study for Introduction a Dry Gravity Separation Process". Prior to drafting of this document, the objectives have been set that would be solved by the strategy, and the same primarily address the following [4]:

- Defining the basic directions of development the open pit coal exploitation for the purpose of continuous, stable and reliable supply of the Thermal Power Plant Gacko with coal of appropriate quality;

- Defining the optimal technological parameters of the system of open pit exploitation on the basis of the results of conducted analysis and optimization based on the economic criteria;

- Optimal utilization the existing coal resources in the area defined by the Program task;

- Determining the possibilities and conditions of application the new technologies of coal exploitation and processing in order to optimize the techno-economic parameters, i.e. to maximize the financial effects of production with improvement quality of produced coal.

The domain of solution for development the open pit exploitation in the Gacko coal basin is formulated within the following limitations:

- The south and north boundaries of the studied area is defined by the limits of open pits and landfills, according to the Regulation Plan of the Mine and Thermal Power Plant Gacko (2011);
- The east boundary is defined by the existing work front;

- The west border is represented by a geological-exploration profile 55-55'.

After determining the essential parameters of the open pit exploitation, based on the adopted criteria, ranking of the considered alternatives was carried out and thus formed the basis for making decisions on the future development of both the mining and thermal power part of the Mine and TPP Gacko. The expected results of the Strategy are also the formation of technological solutions for coal exploitation and processing, which will represent a framework for opening and development the future Gacko open pit and the basis for mining design.

The future development and level of coal production from the Gacko deposit will depend mostly on the production of electricity in the active Gacko 1 Thermal Power Plant and the future Gacko 2. In this case, the basic condition should be fulfilled, i.e. the cost of coal heat utilization, as in many other countries, be at least approximately competitive with the cost of heat from the other primary energy sources (hydro sources, imported energy, etc.). Since the mine and thermal power plant are the unique enterprises, the revitalization of the existing thermal power plant and development of the mine are interco-nnected. Development of the mine will be enabled by the sale of electricity in the surrounding markets (formation of a free electricity market in the region, shutdown of individual power plants in the region, demand for electricity) and improvement the coal processing technology with a possibility of use the lower coal quality. On the other hand, entering the market also means exposure to the price and demand volatility (uncertainty and instability of income). In addition, the future development will also depend on 
tightening the environmental requirements [7].

In order to supply coal regularly to the Gacko Thermal Power Plant, a new conceptual solution for the open pit coal exploitation from the Gacko deposit has been adopted since 2015. Excavation of the overburden, coal and seam waste in the area of Field "C", due to a lack of adequate excavation and transport equipment, has been made difficult with constant delays in the implementation of plans for the open pit excavation. This resulted in a stable supply of coal to the Thermal Power Plant from the active open pit (Field "C"). The conducted optimization of possible variants of development the open pit have highlighted two perspective zones with a possibility of efficient and economically favorable coal exploitation, as well as [3]:

- locality of the Field "C" (Central Field), where the main and first subcoal seams are exploited, and

- roof coal area where the third and second roof coal seams are exploited.

By opening the open pit at the site of the roof coal zone, continuity in the regu lar supply of coal to the Gacko Thermal Power Plant was ensured.

\subsection{Optimum variant of coal exploitation from the Gacko deposit}

A long-term strategy of coal exploitation is elaborated in the "Strategy of Mining and Technological Opening, Development, Optimization and Maintenance of the Coal Production with Introduction the Enrichment Process of Coal of Dry Separation at the Open Pit Gacko", done by the Mining and Metallurgy Institute Bor, Republic of Serbia. The following text briefly outlines the mining-geological and economic indicators of Variant 3, which is elaborated in detail in the Strategy [4].

The open pit boundaries in the in a part of the deposit Field $\mathrm{C}$ and East Field, without limitation by the geological exploration profile 55-55'. Optimization of the Open Pit contour in a plan and by depth was made using the Whittle Fx software.

Figure 1 shows a contour of the open pit from Whittle, designed after processing in the basic software Gemcom.
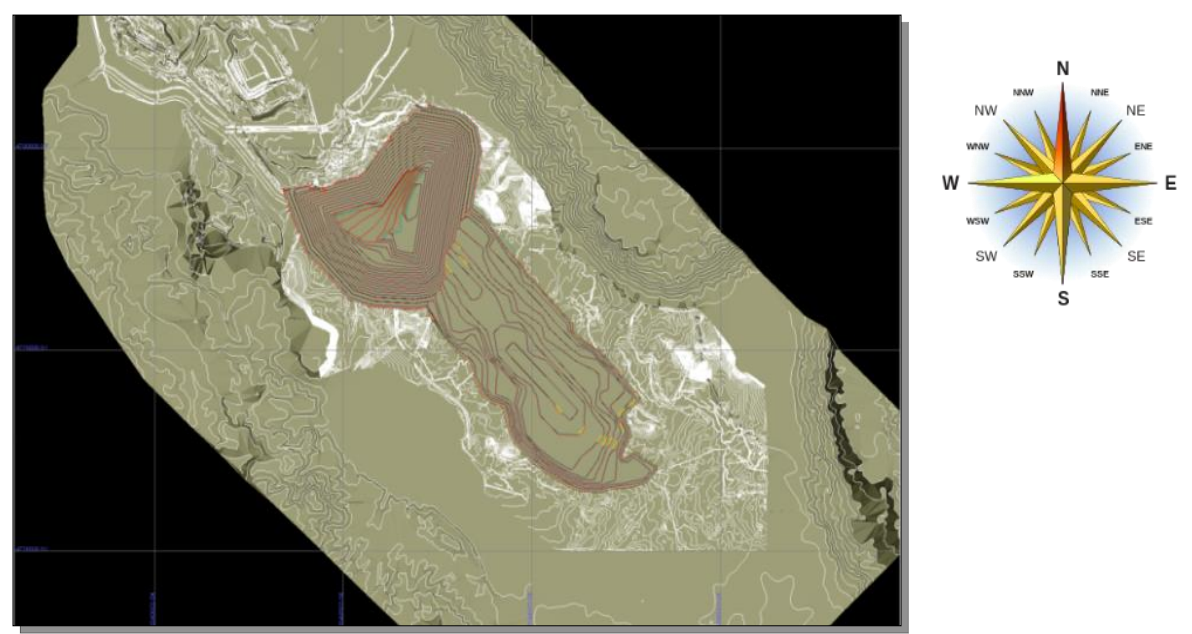

Figure 1 View of the Open Pit 24 designed in the basic Gemcom software on the basis of contours from Whittle (Source: Z.Vaduveskovic, S. Stepanovic et al., 2015) 
Table 1 shows the calculation of coal amount in the roof and floor seams and overburden and associated interlayer waste.

Table 1 Amounts of coal, overburden and interlayer waste in a contour of the Open Pit - Variant 3

\begin{tabular}{|l|c|c|c|c|}
\hline \multirow{2}{*}{ Mineral raw material } & Volume & Volume mass & Amount & DTE \\
\cline { 2 - 5 } & $\mathrm{m}^{3}$ & $\mathrm{t} / \mathrm{m}^{3}$ & $\mathrm{tx} 1000$ & $\mathrm{~kJ} / \mathrm{kg}$ \\
\hline Roof seam coal & $48,246.930$ & 1.300 & $62,721.006$ & $7,393.35$ \\
\hline Main and floor seam coal & $32,231.947$ & 1.263 & $40,722.290$ & $9,531.19$ \\
\hline$\sum$ COAL & $\mathbf{8 0 , 4 7 8 . 8 7 6}$ & $\mathbf{1 . 2 8 5}$ & $\mathbf{1 0 3 , 4 4 3 . 2 9 6}$ & $\mathbf{8 , 2 3 4 . 9 5}$ \\
\hline$\sum$ WASTE 1 & $\mathbf{3 4 2 , 0 4 0 . 4 7 5}$ & $\mathbf{1 . 7 4 0}$ & $\mathbf{5 9 4 , 9 9 4 . 4 6 8}$ & \\
\hline$\sum$ EXCAVATION & $422,519.352$ & 1.653 & $698,437.763$ & \\
\hline \multicolumn{2}{|l|}{$\mathrm{K}_{\mathrm{o}}=3.04 \mathrm{~m}^{3} / \mathrm{t} ; 5.75 \mathrm{t} / \mathrm{t}$} & \\
\cline { 1 - 4 } &
\end{tabular}

(Source: Z. Vaduvesković, S. Stepanović et al., 2015)

Based on the needs of the thermal power plant for an adequate amount of energy, the service life is 36.5 years. Considering the qualitative and structural characteristics of coal from the Central Field deposit, using of only selective exploitation cannot ensure the stable production of coal of the minimum required quality. Based on the conducted research, the X-Ray sensor method of coal separation/refining was adopted for further elaboration.

An overview of the work dynamics over five-year periods is given in $\mathrm{Ta}$ ble 2 .

Table 2 Dynamics of the work development in Variant 3

\begin{tabular}{|l|c|c|c|c|c|c|c|}
\hline \multicolumn{1}{|c|}{$\begin{array}{c}\text { Exploitation period } \\
\text { (years) }\end{array}$} & $\mathbf{1 - 5}$ & $\mathbf{6 - 1 0}$ & $\mathbf{1 1 - 1 5}$ & $\mathbf{1 6 - 2 0}$ & $\mathbf{2 1 - 2 5}$ & $\mathbf{2 6 - 3 0}$ & $\mathbf{3 0 - 3 6}$ \\
\hline Run-of-mine coal (x1000 t) & 13,12 & 14,049 & 14,25 & 14,87 & 15,612 & 15,519 & 18,561 \\
\hline $\begin{array}{l}\text { Run-of-mine coal on a } \\
\text { landfill (x1000 t) }\end{array}$ & 6,100 & 3,973 & 4,206 & 4,863 & 5,607 & 5,519 & 6,561 \\
\hline $\begin{array}{l}\text { DTE - run-of-mine coal on } \\
\text { a landfill (kJ/kg) }\end{array}$ & 7,664 & 8,188 & 8,337 & 8,043 & 8,317 & 8,380 & 7,844 \\
\hline $\begin{array}{l}\text { Refined coal on a landfill } \\
\text { (x1000 t) }\end{array}$ & 4,606 & 6,610 & 6,588 & 6,566 & 6,563 & 6,560 & 7,872 \\
\hline $\begin{array}{l}\text { DTE - refined coal on a } \\
\text { landfill (kJ/kg) }\end{array}$ & 9,318 & 9,626 & 9,865 & 9,088 & 8,201 & 8,433 & 8,657 \\
\hline $\begin{array}{l}\text { DTE - coal on a landfill } \\
\text { (kJ/kg) }\end{array}$ & 8,375 & 9,086 & 9,270 & 8,643 & 8,255 & 8,409 & 51,942 \\
\hline Total energy on a landfill (TJ) & 89,675 & 96,155 & 100,01 & 98,789 & 100,458 & 101,568 & 119,609 \\
\hline Total waste (x1000 t) & 81,277 & 81,397 & 95,972 & 96,833 & 82,543 & 88,342 & 68,630 \\
\hline
\end{tabular}

(Source: Z. Vaduvesković, S. Stepanović et al., 2015)

The basic economic indicators of presented in Table 3. exploitation for the adopted variant are 
Table 3 Economic indicators of Variant 3

\begin{tabular}{|c|c|c|}
\hline \multirow{4}{*}{$\begin{array}{l}\text { Calculation of economic indicators, was } \\
\text { made taking into account, in addition to } \\
\text { the capital and operating costs of the } \\
\text { mining section, also the investments in in } \\
\text { refining plant, standardized costs of the } \\
\text { refining process and benefits generated in } \\
\text { the thermal power plant. }\end{array}$} & Profitability indicator & Variant 3 \\
\hline & Internal rate of return $(\%)$ & 16.66 \\
\hline & Net present value (KM) & $467,010,627$ \\
\hline & Return period (years) & 7 \\
\hline
\end{tabular}

(Source: Z. Vaduvesković, S. Stepanović et al., 2015)

Based on the performance indicators, the coefficient of waste and contoured coal reserves, the Variant 3 was selected as the most economically advantageous because it shall ensure regular supply of coal to the Thermal Power Plant Gacko 1 and future Thermal Power Plant Gacko 2.

\section{NATIONAL COST-EFFECTIVENESS OF COAL USAGE FROM THE GACKO DEPOSIT}

In the previous coal and electricity production from the power complex Gacko, a commercial viability was achieved, which is a direct financial benefit to the energy sector of the Republic of Srpska. However, the commercial viability, which is practically determined by the market economy and its principles, cannot give a clear picture of contribution the coal and electricity production to the national economy of the Republic of Srpska.

In order to measure the contribution of coal production to the national economy, it is necessary to consider the national costeffectiveness, considering the direct and indirect effects of interest to the Republic of Srpska and its long-term and stable development. National profitability from the Gacko Energy Complex is achieved through the positive effects on employment, foreign exchange inflows and international competitiveness. The effects on employment were achieved through employment of a large number of working-age population of Gacko and neighboring municipalities and foreign exchange inflow through the sale of electricity to the foreign market. The international competitiveness of the national energy sector of the Republic of Srpska is characterized by the ability of energy companies for successful engagement in the international economic relations. The Gacko energy complex achieves the same through the production of goods (coal and electricity) that can meet the international market standards, but at the same time retain and increase a long-term real household income. Due to a high demand for commercial coal, as well as a high electricity demand of the countries in the region, it is expected that the coal prices will increase in accordance with the market principles, in comparison with the current state of free pricing at the company level.

Sustainable use of the coal energy resource in Gacko offers a solution for achievement the basic objectives related to the security of supply the present and future thermal power plant, as well as rationalization in its exploitation. This would provide the conditions to the future generations to use the coal resources within the timeframe and reserves available to Gacko. The main objective in the mineral strategy of this resource is to provide the all necessary preconditions for rational and efficient management and sustainable use of available energy potential in relation to the established reserves, envi- 
ronmental impact and socio-economic development.

\section{CONCLUDING CONSIDERATIONS}

The role of thermal power sector that uses coal as a non-renewable energy source is to support the development and growth of the economy of the Republic of Srpska considering the environmental protection. The development of thermal power sector will result in technological development, strengthening of domestic companies, increase of investments and increase of competitiveness of the economy of the Republic of Srpska in relation to the coun-tries in the region. The Gacko mine and Thermal Power Plant have a significant position in the energy sector of the Republic of Srpska. In the strategic document, the countered coal reserves of the Gacko Coal Basin enable a regular supply of coal to the TPP Gacko 1 TPP Gacko 2, and the remain-ning reserves not treated by the selected Variant 3, represent the basis for further mining-geological and economic analyzes and represent the base for construction another one thermal power plant (potential Gacko 3).

The design solution, combined with the coal exploitation from the Field "C" and roof coal zone, provides an economically optimal coefficient of overburden and continuity of coal exploitation from the Gacko deposit.

The planned use of the coal energy resource in Gacko offers a solution for achievement the basic objectives related to the secure supply of the present and future thermal power plant, as well as rationalization in its exploitation. This would provide to the future generations the conditions to use the coal resources within the timeframe and reserves available in Gacko. The main objective in the mineral strategy of this resource is to provide the necessary preconditions for rational and efficient management and sustainable use the available energy potential with respect to the established reserves, environmental impact and socioeconomic development [7].

\section{REFERENCES}

[1] Milovanović D. (1991): Some Current Issues of Economic Evaluation the Mineral Deposits in Market Conditions, Tehnika, Rudarstvo, geologija i metalurgija, No. 3-4, Belgrade (in Serbian)

[2] Nikolić D. at all. (2013): Elaborate on Coal Reserves in the Gacko Deposit with Condition as of 30/06/2012, GEOING-group, Belgrade (in Serbian)

[3] Vaduvesković Z. (2014): Presentation of the Conceptual Design for Development the Coal Mine Gacko, MMI Bor, R. Serbia (in Serbian)

[4] Vaduvesković Z., S. Stepanović: (2015): Strategy of the MiningTechnological Opening, Development, Optimization and Maintenance a Continuity in Coal Production with Introduction a Refining Coal Method of Dry Separation at the Open Pit MMI Bor, R. Serbia (in Serbian)

[5] Vuković B., Petrović M., Petrović P., Bijelić V., Stanimirović B. (2004): Possibility of Improvement the Quality of Coal from the Open Pit "Gračanica" Gacko by Introduction the Paranaby Technology, Scientific and Professional Conference "Contemporary Achievements in the Exploration, Exploitation and Use of the Mineral Resources in the Republic of Srpska", Gacko (in Serbian)

[6] Vuković B. (2000): Complex Assessment of the Gacko Coal basin and its Importance for the Overall Energy Potential of the Republic of Srpska, Master Thesis, Faculty of 
Mining and Geology, Belgrade (in Serbian)

[7] Vuković B. (2011): Geological-Economic Assessment of the NonRenewable Energy Resources of the Republic of Srpska in Function of the National and Commercial Viability, Doctoral Dissertation, Faculty of Mining and Geology, Belgrade (in Serbian)
[8] Vuković B. (2018): Book of Coal Reserves of the Gacko Coal Basin Condition as of 31/12/2018, Gacko (in Serbian)

[9] www.vladars.net, Strategy of Energy Development of the Republic of Srpska (in Serbian)

[10] www.energetika.blogger.ba, Energy Sector of B\&H. Coal Mines and Prices (in Serbian) 